\title{
Histological Studies on the thyroid gland of normàl and bilaterally adrenalectomized rabbits with special reference to interaction between the thyroid and the adrenal
}

by

\section{Ikuo MURONE}

Department of Internal Medicine, Niigata University, School of Medicine (Director: Prof. M. NISHIKAWA)

In order to clarify the interaction between the thyroid and the adrenal, histological studies were performed on normal and bilaterally adrenalectomized rabbits. For this experiment, 14 adult male rabbits were sacrificed, 3 as control, 11 adrenalectmized. Extirpation of the adrenals was orried out on two times, first on the right and after 7 days on the left.

The results were as follows:

1) In the normal rabbits' thyroid, there were PAS -positive granules in the cells of follicular epithel as well as inside of the follicles.

Such granules in the follicular epithelial cells accumulated near the colloidal sides from the supranucler parts and then it seemed that the PAS positive granules may be secreted into the lumen of the follicles.

2) A few thin ductlike structures were recognized between epithelial cells, with were stained by the PAS method, and passed through epithelial wall from the follicle lumen to the interstitium. But they were seldom found among the rabbits with lived more than ten days after bilateral extirpation of the suprarenal glands.

From this it is surmised that the functional changes of the thyroid glands may influence upon the existence on the ductlike structures.

3) There was a basement membrane-like structure at the base of the follicular cells which was PAS positive.

4) The adrenalectomized rabbits which lived more than ten days after bilateral extirpation showed that all follicles began to be filled with the PAS positive colloid meterials and the height of the epithial cells became lower and those tendencies were maximum in the survials of 25 days.

Judging from these findings, it seems that both production and discharge of the thyroid hormones would be disturbed in the bilaterally adrenectomized rabbits but the latter may be more markedly inhibited.

The main causes of these phenomena may be attributed to the following two factors: the one is the decrease of TSH secretions from the pituitary gland and the other is the decrease of the thyroxine consumption rate at the peripheral tissues.

5) And thus, within the limited extent of this experimental study, it seems likely that there is a synergic relationship between the functions of the thyroid glands and of the suprarenal glands. 


\title{
正常家鬼甲状腺組織像に関する二、三の検討、及び 雨側副腎摘出後に於ける甲状腺の組織学的変化
}

\author{
新潟大学医学部西川内科教室（主任 西川光夫教授） \\ 室 根 郁 男
}

本論文の要旨は昭和 32 年 4 月日本内分泌学会総会に於て発表した。

緒 言

近年甲状腺の組織学的研究に比較的新しい方法に依る研究がなされている. 例えば Lebond，C.P.; J. Gross (1948)131の I ${ }^{131}$ Radioautograph 亿依る知見，Brausteiner. H.K. et al ${ }^{4}$. (1953) の正常及び TSH 投与ラッ

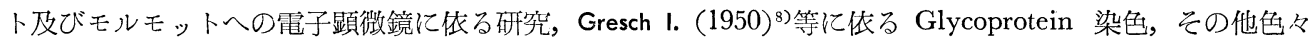
の組織化学的応用などである.

私は PAS 染色を用い，甲状腺組織学上の二三の問題を検討した。

次に甲状腺と副腎との機能的相関に関してであるが，乙れは古くから注目され，1926年 Schmidt，M.B ${ }^{27)}$. は臨床及び病理解剖の面から下垂体が組織学的に正常であるにも拘らず臨床上 Addison 氏病であると同時 に甲状腺機能低下を来たし，その病理組織学的所見に於て副腎及び甲状腺に萎縮を証明した症例を報告した。

謂所 Thyreo-Suprarenaler Typus 又 Schmidt's syndrom と呼ばれるものの始めである. かつる症例は其 後幾つか報告されているが最近では Bloodworth， J.M.B.; W.M. Kirkendall; J.L. Carr (1954) 亿) に依り報告さ れているててれに反し Rössle (1914) ${ }^{24)}$ は Basedow 氏病を伴う Addison 氏病の一例を報じてる.更に Pa-

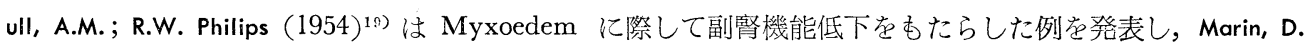
$(1930)^{14)}$ は甲状腺機能昂進症特に Basedow 氏病に於て副腎機能の低下を見たと報告している.

以上の主なる臨床報告例に於ても, 甲状腺と副腎との相互機能的相関のあるととはほぐ確実であるが，一 方の機能低下が他方の機能低下を来たすのか他方の機能昂進が一方の機能低下を生ぜしむるのか帰一する麻 がない，てのことは動物実験に於ても然りである。主なる今迄の実験結果を通覽するに，Money, K. et al. $(1951)^{16)}$ は ACTH, Cortisone が甲状腺の I ${ }^{131}$ の集積を減少せしめると云い, Hill, S.R. : Reiss, R.S. et al. $(1950)^{10)}$ の Corticogenic Hypothyrodism を確めた. PBI の面であ Perry, W.F. (1951) ${ }^{20)}$; A. A. Abert (1951)1) は Cortisone, ACTH がラットの PBI を低下せしぬたと報じている。

然し逆の結果に到つた実駼報告あある。即ち組織学の面から O'Neal 及び Heimbecker, P(8) はラット及び 犬に於て Cortison の長期投与は PBI に変化をもたらさないし，甲状腺重量及びその組織像も影響されな い事を観察した。高折 (1955) ${ }^{29)}$ も cortison 投与が Plasma PBI ${ }^{131}$ 及び全血漿 PBI ${ }^{131}$ の減少とラットの甲 状腺重量增加と機能无進像を認ぬ，Higgins，G.M., K.A. Woods \& E.C. Kendall (1951) ${ }^{11}$ は cortison 投与ラッ トの甲状腺上皮細胞の高さの増加を見て, 甲状腺機能克進とした。

以上通観するに臨床例，実験動物例何れも甲状腺及び副腎機能の相関についてははたして拮抗的なりや，

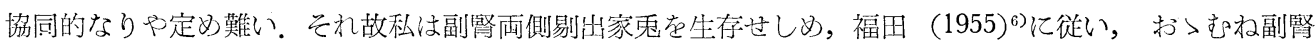
摘出に依るが Stress 回復し，副腎脱落症状観察可能と考えられる両側副腎摘出後10日後より約20日間にわ たる期間甲状腺を組織学的に検討した。

\section{実 験 方 法}

雄性正常成熟家躳体重 $2 \mathrm{~kg}$ 前後のもの14匹を使用し, 3 匹を対照群とし,11匹を両側副腎摘出生存群とし

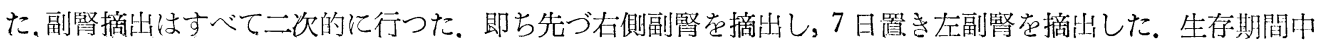


の飼糧はオカラ，青菜の一定飼糧を用いて，特には副䌓脱落に対する処置等は行わなかつた，生存せしぬた 期間は摘出後10日，14日，25日，30日間であつた。

なおこ〉に揭げた副腎摘出群の11匹は全実験家鬼総数30匹中両側摘出不完全なもの，及び摘出後体力消粕 はなはだしきものはすべて除き，比較的長期生存に堪え，元気のあるもののみの匹数である。

次にてれらの生存例について，上記の生存せしめるべき日数に従つて Isomytal prokg $0.05 \mathrm{~g}$ に依り麻醉 後目的とする甲状腺を採取し Orth 氏液及び Bouin 氏液にて固定せしめた. 其後型の如く paraffin 包埋,

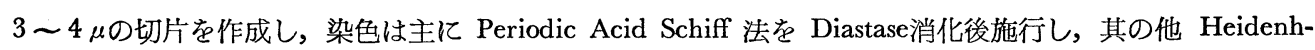
ein の Eisen Haematoxylin 法に依つた. 時に H・E染色, Azan 染色を併用して観察を行つた.

これらすべての副腎摘出実験及びその生存期間は10月より 2 月下旬頃迄の冬期に施行したものである.

なお滤胞上皮細胞丈の高さ及び滤胞腔口径は Ranson, R.W. : D. Starr (1938) ${ }^{23)}$ にならい Ocular-Schrauben Micrometer ↔用い計測した。細胞丈に於ける細胞計測個数は100個である。

\section{観 察 所 見}

\section{a）正常組織像}

全体として冬期に於ける家躳甲腺組織像はコロイドの充満せるものは少く，辺緑空胞を有するすの多数を 占める，濾胞上皮細胞は立方形なるすの大多数にして，時に扁平なるもの，円柱形なるものか混在している. 細胞の丈の高さは平均 $6.34 \mu$ である。核は円形乃至は卵网形で比較的大きい. 核小体は 1 一数個を見る. 濾 胞腔口径は大小種々あり，小なるあのは約 8.8 位のあのより，大なるものは $88 \mu$ 位にあ及ぶ. 平均は約 $22, \iota$

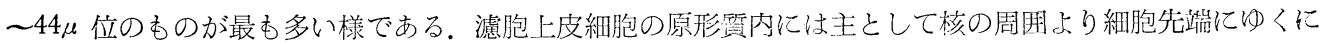
つれて可成著しい陽性顆䊀の存在を認め，特に滤胞腔側に沿い多量に見々れる。一部顆䊀方濾胞腔中に分泌 されている組織像も見る。

コロイドは赤染色に PAS 陽幽を示し, 厚く, 一様に染色されるものから, 瀻細な顆粒の集積像更に濾胞 内に全く存しないもの迄種々の程度に見る。濾胞腔の形は卵门形又は長楕円形のむのが多い。濾胞上皮が濾

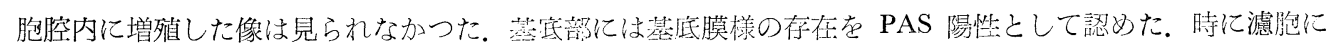
皮細胞間に PAS 陽幽にて染色される隔膜様の細隙を見ることあり，特野 (1952) ${ }^{12)}$ が導管と呼ぶところの あのと思考される。一般に細胞基底部は明るく，時に空胞の存在を認少る。ミトコンドリアは濾胞上皮細胞 中に散在しており，特に集つていると云つた部分はない，核の周用，基底側及び滤胞側にも存する。一般に 顆粒状のあのが多い，又鉄へマによつて染色される分泌顆粒と思われるものが細胞先端にあることあある. 然し中には顆粒状ミトコンドリアが縦列している細胞す認邓た。滤胞腔側に比較的多くミトコンドリアが存 在する場合もある.

b) 両側副腎摘出後の甲状腺の組織学的変化

副腎全摘後10日目生存の 2 例の甲状腺の組織学的所見では全視野にわたつてコロイド充満せるあの多くな り, 所々辺縁空胞の存在を見る。コロイドは全般的に一様に染色され，各滤胞腔内に略同程度のコロイド量 を有している，対照コロイドに比輘して赤紫色の程度が強いあのが多い，滤胞の形は円形又は卵円形のもの 多く，比較的不規則な形状のものは少くなる．滤胞上皮細胞は大部分扁平化され，所々立方形の細胞を混し ている，細胞丈の高さは平均 5.33 . であり，刘照に見られる如き核上部より細胞先端に迄存在する陽性顆粒

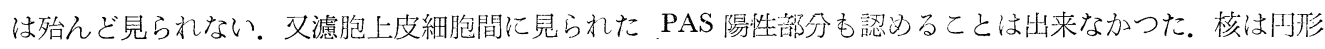
又は卵円形なるものに混つて，桿状なるもの，扁平なるすの等がしばしば散見した。ミトコンドりアは減少 し，繊細微少顆精を呈している。

副腎摘出後14日生存例 3 匹では全視野の滤胞腔のコロイドが充満像に近い像をますととは10日目後所見と 略類似であり，辺縁空胞は所々散兒する絽度に減少している。コロイドは一般に同一濃度の染色態度を示し

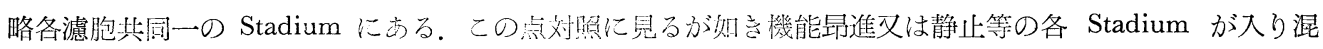
つているが如き像とは著しく相違する。滤胞腔径の大きさは中等度より大なるものが多くなり，平均 $44 \mu$ 程 
度のむのが最む多い，その形状は殆んど卵円形及び円形のむのが支配的である．滤胞上皮細胞の丈の高さは 扁平化せるあの多く, 平均 $1.1 \mu \sim 2.2 \mu$ の間のあのが主であつた。 中には立方形なるのもあ多少とも混つて いた. PAS 陽性分泌顆粒の細胞内の存在及び細胞間隙に見られる PAS 陽性部分は前同様に認め難い。核は 桿状のものが多く，その中に卵円形，円形状のものが混つている。一部核が淩縮せるもの又は融解消失せる 像むある。ミトコンドリアは10日目所見より更に減少，増々微細顆粒となり認め難くなる。

副腎摘出後25日目生存例 3 匹では全視野の滤胞腔内はコロイドに依り全く充満せしめられ，PAS 染色に より強度赤紫色に，又全体均䆩に反応し，可成厚く，辺緑空胞と云うべきものは全く存在しない，典型的な コロイド充満組織像であつた。濾胞腔の形状は卵円形のもの, 円形のもの, 梯状形様のもの等色々存在し, 非常に濾胞腔径大なるものが多数を占有する. 即ち中等大のものより更に大なるあのが大部分を占め, $44 \mu \sim$ $66 \mu$ 平均のものを中心に $77 \mu \sim 88 \mu に$ 到るものも散在する。そえれ故滤胞上皮細胞は充満コロイドに依り圧迫さ れているが如き組織像を示している。そして滤胞上皮細胞の可成の扁平化之萎縮に近い像を見る。細胞丈は $1 \sim 2 \mu$ 位である. 立方形のあのは先づ殆んど見あたらない，原形質は一般に暗調であり，PAS 陽性顆粒 なく，細胞間隙 PAS 陽性部分も認妨々ない，核は大部分が桿状又はそれ以上扇平なもののみであり，時 に萎縮し，pyknotisch と云うべき像である。ミトコンドリアは減少著しく原形質は鉄へマトキシリン染色 にて均質に見える。25日後のか〉る組織学的所見は典型的な甲状腺機能低下組織像を示していた。

30 日後生存例 3 匹では大体 25 日目見と類似しているが所及辺縁空胞も見られる箇所もあつた。滤胞腔径は 約 $44 \mu$ 以のものが多い，滤胞上皮細胞は全体として扁平化したまつであり，一部は25日後所見よりも萎縮， 崩壊像を認める。乙の埸合の細胞丈は $1 \mu$ 末淦のむのが在した。核は桿状を呈するが著しく pyknotisch な るむのが多かつた，原形貧は一般に暗調にして PAS 陽性顆粒も勿論，細胞間隙と云われるべきPAS 陽性

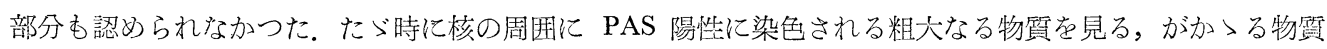
は変性産物ではないかと法えられる。間筫の変化については明らかでない。ミトコンドリアは全体として減 少しているが，核の周辺に少しく絲状浔認めらる場合もある。

以上30日後の所見は全体として25日後所見に比し，滤胞上皮細胞の変坐が高度であるが，しかし一部わづ かながら25日目の所見に比し組織学的野に機能が良好と思われる部分ああつた。

\section{考按}

狩野 $(1952)^{12)}$ は人体材料を用い，正常及び Basedow 氏病の甲状腺組織像をPAS 染色飞依り検索し，滤 胞コロイドが赤紫色に PAS 陽性に紫色されること，又分泌顆粒も染色されること，更には Basedow 氏病 甲状腺に於て細胞間除と解される PAS 陽性部分の存在を指摘している。乙の組蟣学的知見より，コロイド の滤胞上皮細胞再吸収説に対して疑議を提し，細胞間細管通過説を主張している。私が正常家鬼甲状腺組織 像に於て観察した所です Wallraff, ; H. Becker. $(1939)^{311}$, Gresch, I. (1950) ${ }^{8)}$ 等の報告の如く, 滤胞コロイド はPAS 陽性に染色され赤紫色を呈する。又滤胞上皮細胞に於ても核真下部位上り細胞先端に向い，特に濾 胞腔に沿い，PAS 陽性の分泌顆粒を認》た。乙の分泌顆䊀か恐らくは滤胞腔コロイド構成部分として腔内 に分泌せし邓られるあのと落えられる。而もこの物賢が Diastase 消化後に認められている事から Glycopr-

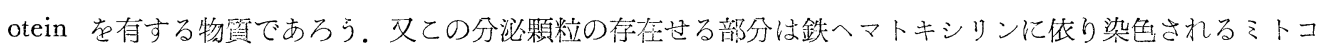
ンドリアも存するし，分泌顆粒それ自身も染色されているととなどは梱液腺条絞部細胞に見らる〉 PAS 陽

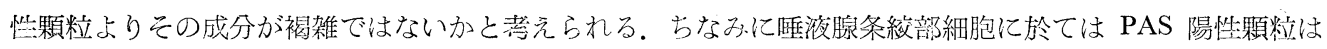
ミトコンドリア存在部位に無かつたし，鉄へマにて PAS 陽性顆粒は染色されなかつた

以上の事から甲状腺滤胞細胞内陽性分泌顆粒及び PAS 陽性コロイドは Thyroglobulin を含有する所の Glyco-Lipo-Protein Complex してあるとあのと推察される。

次にコロイド血中放出機構に関する細胞間の細管部通過については，Mcciendon，J.F. (1939) ${ }^{15)}$ が超遠心法 により細胞間にコロイドが通過すると思われる間隙を認り，前揭の狩野 $(1952)^{12}$ あ Basedow 氏病 の甲状腺に於て可成著明に陽性部分孛細胞間に锥察し，導管通過説を主張している．私も正常冬期家鬼に於 
て時々かかる像を見た。しかし後述する如く,副腎摘出家鬼には殆んど観察されない事から,ての部分が何ら か甲状腺機能と関係があるととは明かと思われる。基底膜の存在に関しては未だ磪定的に述られていないが

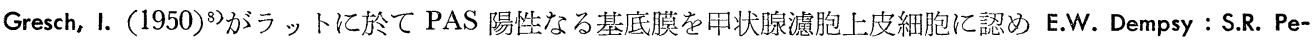
terson (1955) ${ }^{5)}$ も電子顕微鏡を用いてラットの甲状腺滤胞上皮細胞基底部に於て二重構造を有している電顕 像を認めている．私も前述の如く家鬼甲状腺組織像に於て PAS 陽幽基底膜様の存在を指摘し得ることから はたしててれが基底膜なるが導管様構造物なのか，今後の検討を要する所であるが，甲状腺濾胞上皮細胞に 基底膜の存在している場合むあり得るとと〉思われる。

次に副篮と甲状腺との相関関係であるが，諸言にも述た如く，臨床例及び動物実験例の結果から見ても単 純ではない. 特に cortisone, ACTH 投与時に於ける甲状腺の $\mathrm{I}^{131}$ 掑取率，PBI，及び組織学上の所見は特に その感が深い.

一方両側副緊摘出に於ける実験は1939年，Schulze，E. : K. Mellinghof ${ }^{26)}$ が副筒摘出後 3 日間生存せしめた

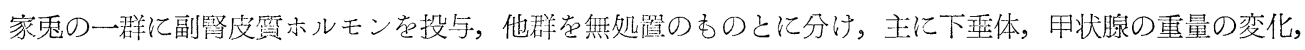

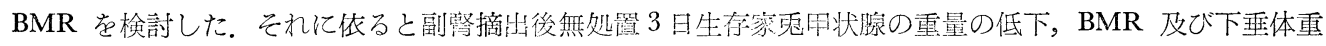
量の低下を報していた。竹村 $(1955)^{30)}$ 汶ラットに知いて副整摘结が組織学的に甲状腺機能低下像を示した

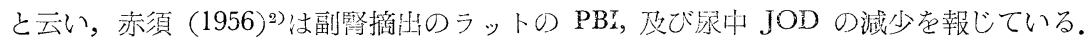

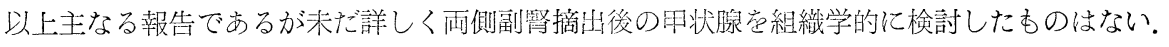

本実験の結果上り孝察するに副篮摘出手術の影響が活ぐ回復したと見られる摘出後10日目よりコロイバ充 満像が增え，滤胞上皮細胞の扁平化の湎问が蕒明となり，25日に於て最屯典盟的なコロイド充満と，濾胞上

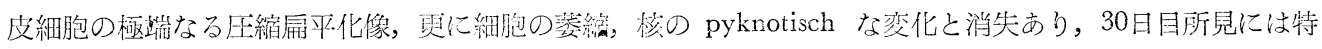

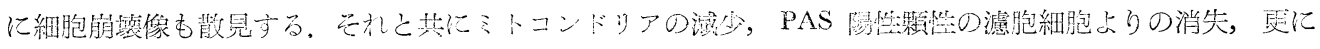

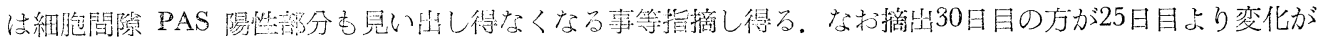

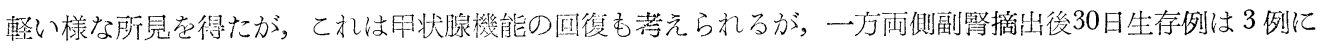
過ぎず副々腎の存在を否定することも出来ない，剖検によつては副々腎の存在を確め得なかつたが，軽微の 副腎機能の残存により30日間も生存が出来かつ本状腺の組織像も25日目のものより変化が軽かつたとする方 が考㝋易い.

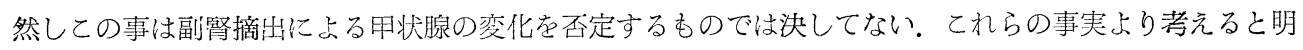
かに甲状腺機能低下を示す緼織像であるが，甲状腺ホルてンの分泌及び血中への放出という二面の㗢きを考

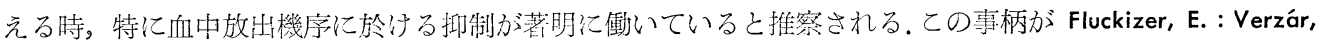

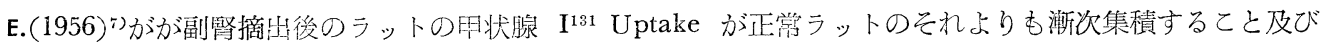

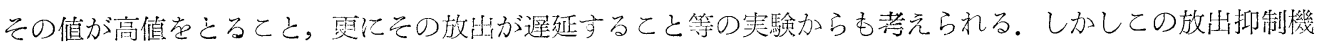
構が如何なる機序に依り発生するやは推諭の域を出ないが大体二つの大きな考光にすとめられると思う。即

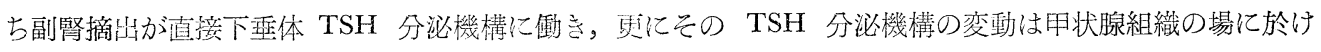
る Enzym機構に影響し，Thyroglobulin 右 Thyroxin として放たしめる Protease 等の Enzym が円滑に働 かないという推定及び末稍血中父は細織に於けるThyroxin 消費が副腎ホルモンの減少に依り低下している

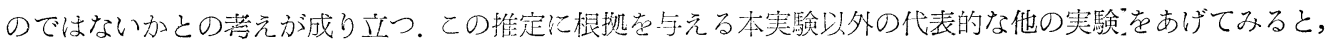
Halmi, N.S. (1952) 9)の行なつた Cortison 投与ラットの下垂体前葉 $\beta$ 組胞の機能元進組織像及びそれに同時

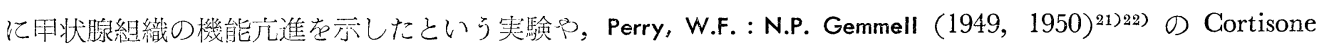
が末稍組織の Thyroxin の消費を高多るという実験等である。乙れ等ずでて Cortisone 投与実験であるが， 副腎摘出がほメ゙その逆な結果芭予想せしめる。この点木实験結界として生じた放出抑制機構に関する推定と 相通ずるものがある。

以上総合的な推察として，副腎摘出は直接下垂体を介し，TSH 分泌を減少せしぬる一方，末稍組織に放 ける Thyroxin 消費の低下をむたらし, 本実験結果に見る如き甲状腺機能低下組織像, 就中コロイド血中放 出機序に抑制的に衔く為巷起された組織像を呈したものと解橎される。 
最後に間質の問題であるが，本実験に於ては大した変化を認めるととは出来なかつた．乙の点前掲の Schmidt (1926) ${ }^{27)}$ 及び Bloodworth,J.B. : W.M. Kinkendall ; J.L. Carr (1954)年等が Addison 氏病の甲状腺に見た 間質に於ける Lymphoid Tissue の增殖や淋巴球の侵潤が副婜摘出のみでは実験動物甲状腺間質に起らぬこ とから，何かその他のメカニズムが加わつているのではないかと考えられる.との点が Russel, J.A. (1950)25) が推測しに副筜皮質ホルモンの欠如が Lymphoid Tissue の増殖の原因であるという説にはいさつか異論が ある.

\section{結論}

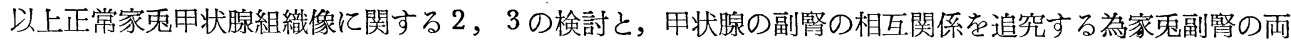
側摘出を行い，副慜説落症状観差可能と考えられる摘出後10日目頃より20日間にわたる間の甲状腺の組織学 的变化を併せ検索した。 その結果次の事が要約された。

1 ）冬期正常家鬼甲状腺胞上皮細胞の核上部より，細胞濾胞腔側にかけ特に PAS 陽性粒があり，これ が滤胞腔に分泌されコロイド成分となるらしい。

2 ）同上家鬼甲状腺濾胞上皮細胞間には所々，PAS 陽性に染色される細管様部分があり，副惄摘出後 10 日目以降の生存家鬼甲状腺に見られないことから，乙の部分が甲状腺機能と何等か関係があると思考される。

3 ）甲状腺濾胞上皮細胞の基底部には PAS 陽性なる基底膜様構造を見る。

4 ）正常家鬼甲状腺組織像は両側副腎摘出捘10日目頃より，組織学的に機能低下像を示す。特に25日以後 に見られる陳旧コロイド充茼像及び，胞上皮細胞の極端なる扁平化は甲状腺ホルモンの合成放出二面のうち 特に放出機序に何等かの抑制があると考えられ，その発生機序としては副缓摘出が下垂体よりの TSH 分泌 を減少しめるとと〉，末稍組織のサイロキシン消費を低下せしめるとととの二面よりの影響の結果ではない かと推測される。

5 ）以上の本実験の範囲内に於いては，甲状腺と副㹂とは機能上協同的に働くのではないかと渃えられる。

本論文作成に当り御指導及び御校閲を賜わつた鳥䭒竜生教授及び西川光夫教授に深謝致します。健宜を 扔与え下された小池上解剖学教室の方々に謝意を表します。

\section{参考文 献}

1) Albert, A.A. : Endocrinol. $50: 324,1951$.

2）赤須文男 : 日本臨床，14:19，1956.

Bloodworth, J.M., W.M. Kirkendall, J., Carr, : J. Clin. Endocrinol. \& Metab. $14: 540,1954$.

Braunsteiner, H.K. et al. : Endocrinol. 53 : 123, 1953.

5) Dempsy, E.W., S.R. Peterson. : Endocrinol. $56: 461955$.

6) 福田篤郎 : 内分泌，11，3，2:207，1955.

7) Fluckizer, E., E. Verzár. : J. of Endocrinol. $13:$ 39, 1956.

8) Gresch, I. : J. of Endocrinol. $6: 253,1950$.

9) Halmi,

N.S., S.B. Barker. : Endocrinol. $51:$ 127, 1952.

10) Hill, S.R., R.S. Reiss et al. : J. Clin. Endocrinol. \& Met. $10: 1375,1950 . \quad 11)$ Higgins, G.M. and K.A. Woods a E.C. Kendall. : Endocrinol. $48: 175$, 1951. 12) 狩野好一郎：日本組織学記録, Vol, 4, n3, P. 240, 1952. 13) Leblond, C.P. a J. Gross. : Endocrinol. $43: 306,1948$.

14) Marin, D. : Amer. J. Sciences, $180: 767,1930$.

15) Mcclendon, J.F. : Endocrinol. $24: 82,1939$.

16) Kraintz, M. et al. : Endocrinol. $48: 682,1951$.

17) 室根郁男 : 新潟医学会誌, $10: 1083,1954$.

18) O'Neal, a P. Heinbecker. : Endocrinol. $53: 239$, 1953. 19) Paull, A.M. aP.M. Philips. : J. Clin. Endocrinol. \&Metab. $14: 554,1954$.

20) Perry, W.F. : Endocrirol. 49 : 284, 1951.

21) Perry, W.F. a N.P. Gemmell. : Canad. J. Research. $27: 32$, 1949.

22) Perry, W.F. a N.P. Gemmell. : Canad. J. Research. 28 : 147, 1950.

23) Ranson, R.W. a Starr, D. : Arch. Int. Med. 61 : 726, 1938.

24) Rössle. : Verhandl. d. Deut. Path. Gesell. XVII, S, 220, 1914.

25) Russel, J.A. : Bull. New York. Acad. Med. 26 : 240, 1950.

26) 
室 根論文附図（その 1 ）

写 真 1

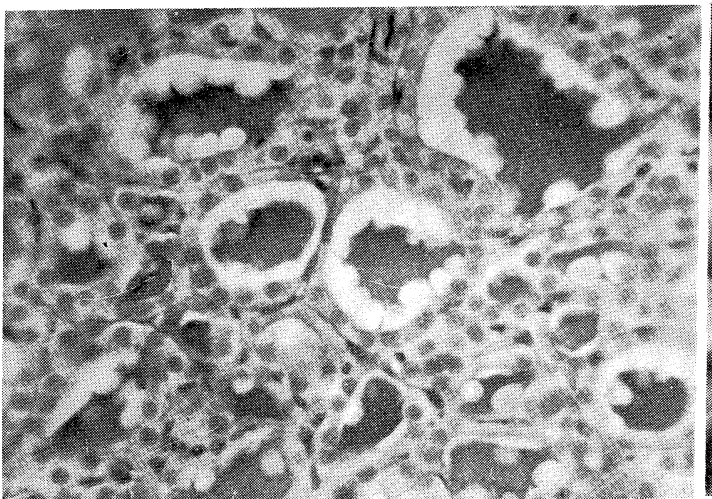

写 真 3

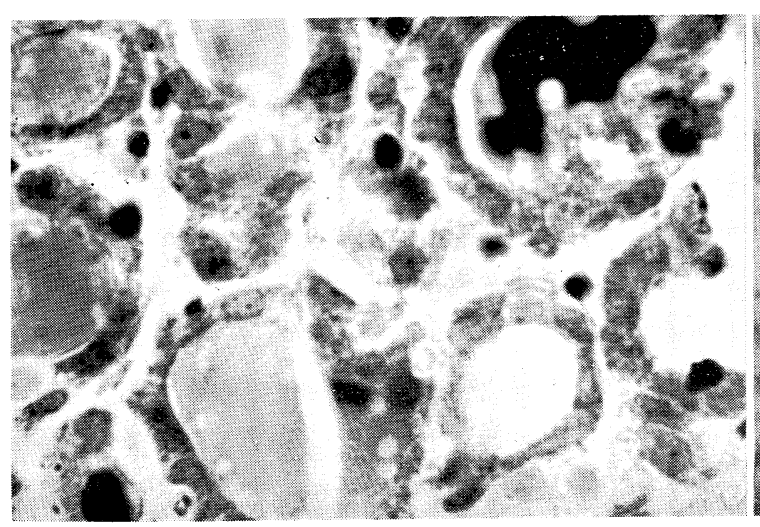

写 真 5

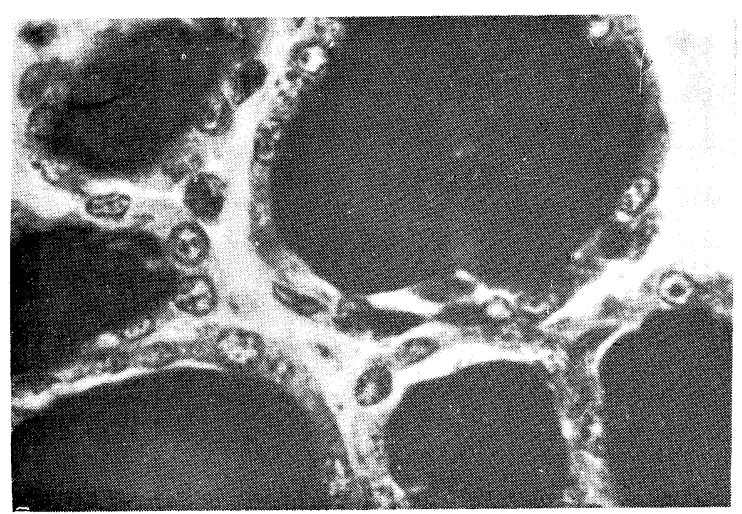

写 真 2

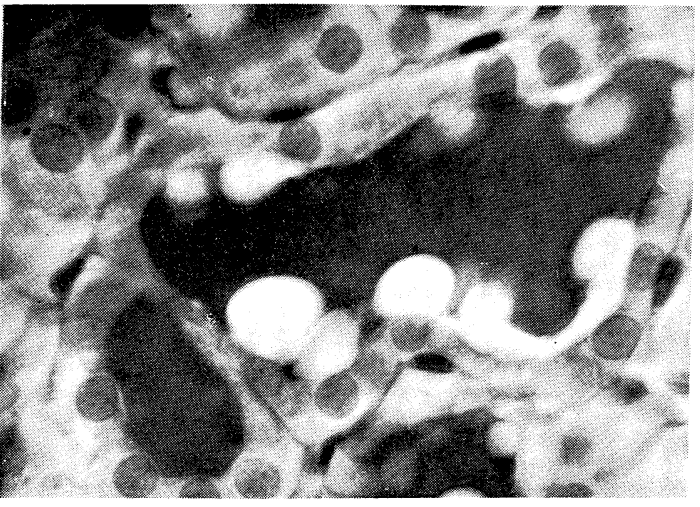

写 真 4

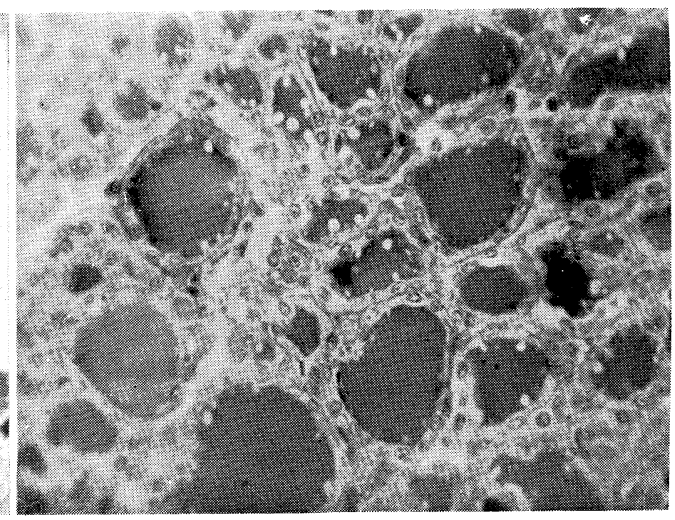

写 真 6

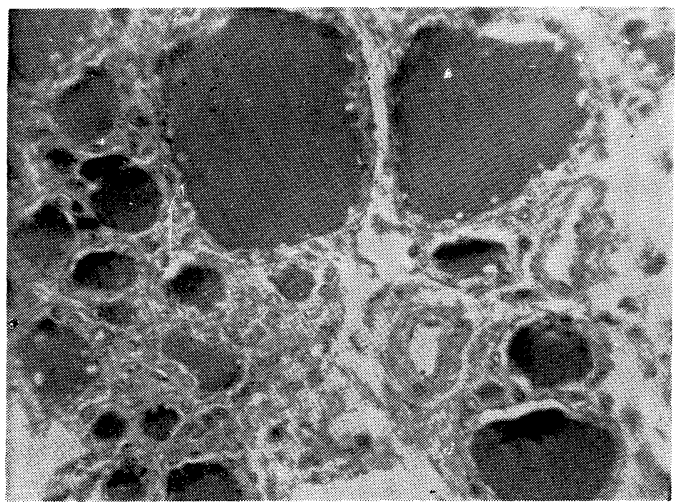


室根論文附図（その 2)

写真 7

写 真 8
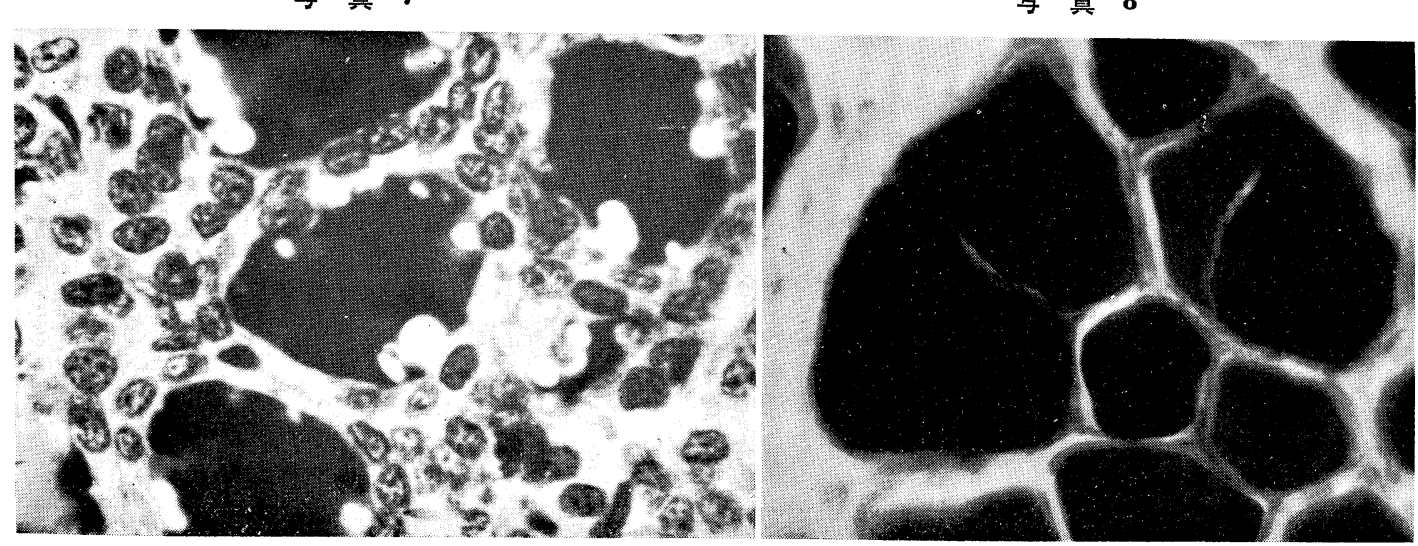

写 真 9

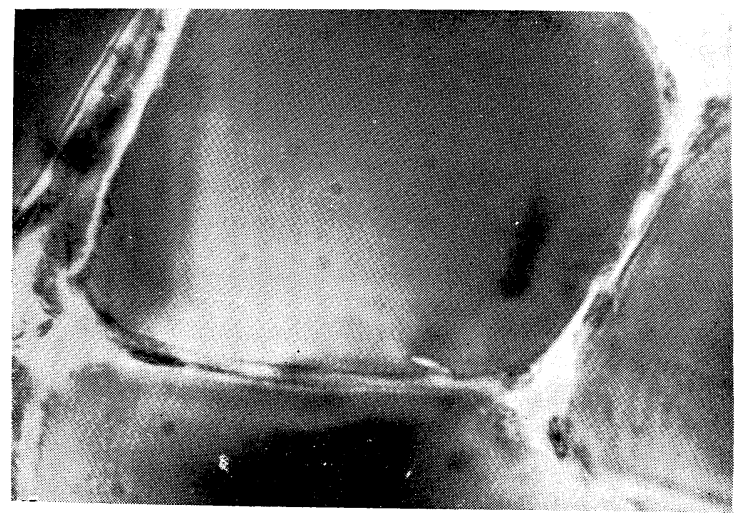

写 真 10

写真 11
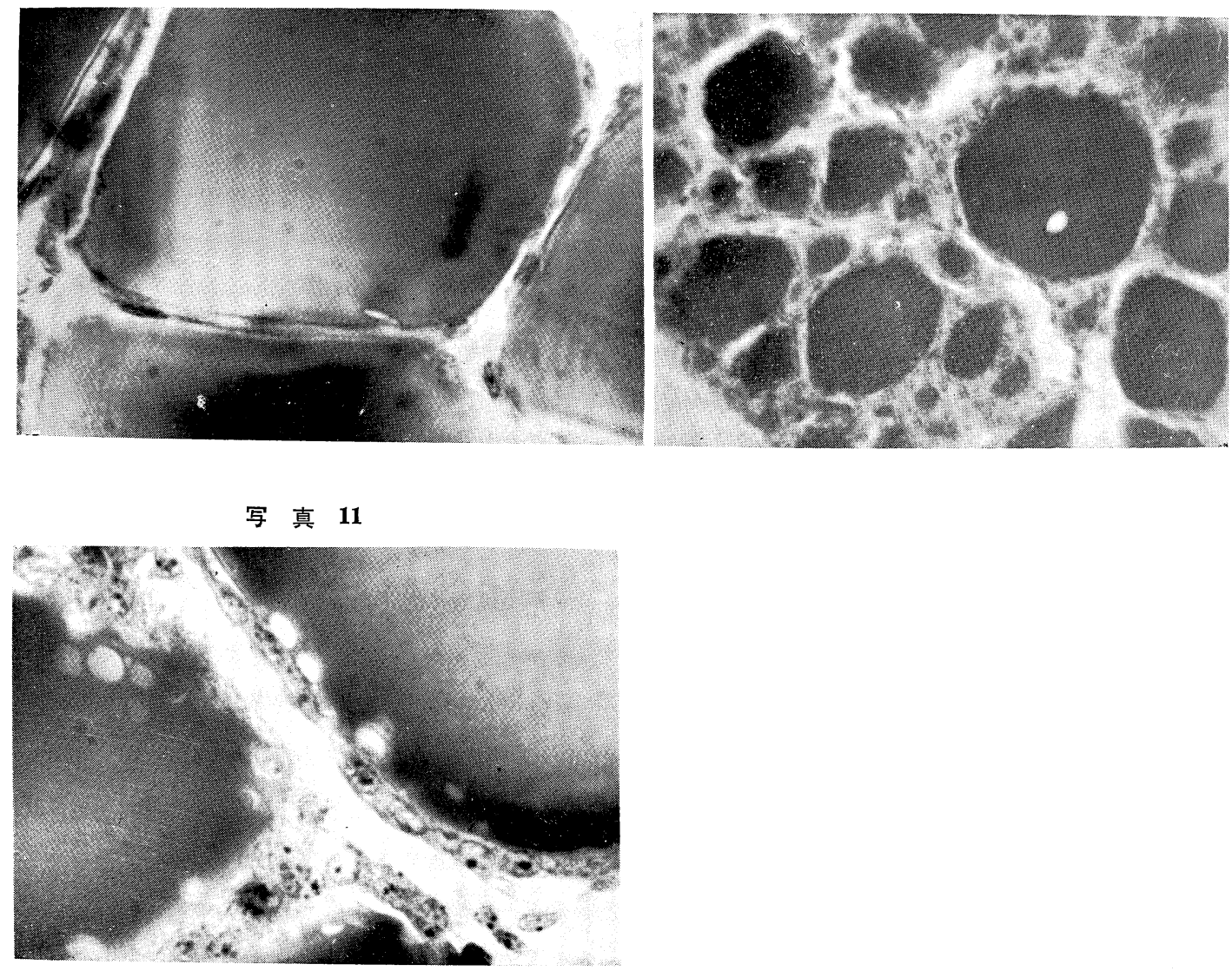
Schluze, E. a K. Mellighoff. : Ztschr. f.d. Gesamte. Exp. Med. 105 : 532, 1939.

27) Schmidt, M.B. :

Verhandl. d. Deut. Path. Gesell. XXI. S. 212, 1926.

28) Shipley, R.A. a F.H. Macintyre. : J. Clin.

Endocrinol. \& Mełab. $14: 309 ; 1954 . \quad 29)$ 喜折忠太：日内分必会誌，Vol，30，n. 10，P. 543，

1955. 30) 竹村久康：日本病理学会会誌総会号 $44: 116,1955 . \quad 31)$ Wallraff, J. U. H. Becker.

: Z. Mikro. Anat. Forsch. 45 : 510, 1939.

\section{附図説明}

写真 1．正常家鬼甲状腺組織像．PAS 染色（×220）辺縁空胞多数，滤胞上皮細胞形恃立方形が主，滤腔 口径は大小混在.

写真 2. 正常家鬼甲状腺組織像。PAS 染色 $(\times 1050)$ 主に核の周囲上り細胞先端に PAS 隄性顆粒あり, 右下細胞間に PAS 陽性の隔膜様細隙を見る. PAS 陽性の基底膜様構造存す。

写真 3. 正常家鬼甲状腺組織像，鉄へマ染色 $(\times 660)$ 核周辺より滤胞腔側にミトコンドリア多く散在す る.PAS 陽性顆粒と一致して存する部分あり．左下細胞に見る如く縦列している部分もある.

写真 4. 副腎摘出後 10 日目家鬼甲状腺組織像。 PAS 染色. $(\times 220)$ ユロイド充满減胞増加。滤胞細胞の PAS 顆粒減し，砽平化の傾向がある.

写真 5 . 副腎摘出後 10 日目家鬼甲状腺組織像。鉄へマ染色. ( $\times 660)$ ミトコンドリア減少し始め，不規則 亿桷漫性に存す。顆粒は瀻細となる。

写真 6 . 副腎摘出後 14 日目家鬼甲状腺組織像. PAS 染色. $(\times 220)$ 辺縁空胞著明飞減少。滤胞腔径大な るもの多し，滤胞上皮扁平化著明，核の萎縮又融解消失像もある。

写真 7. 副腎摘出後14日目家鬼甲状腺組織像。鉄へマ染色. ( $\times 660)$ ミトコンドりア著明に減少せるもの の例. 顆粒微少にして認め難くなる.

写真 8 . 副腎摘出後 25 日目家鬼甲状腺組織像. PAS 染色. $(\times 220)$ 辺縁空胞皆無, コロイド然满. PAS 強度陽性. 滤胞腔極端に拡大上皮細胞扁平萎縮. 原形質暗調

写真 9. 副腎摘出後25日目家鬼甲状腺組織像。鉄へマ染色.（×660）ミトコンドリア殆んど無し。核扁平 萎縮.

写真10. 副腎摘出後30日目家鬼甲状腺組織像. PAS 染色.（ $\times 220 ） 25$ 日目之略同一所見なるも，やや一 部に機能が回復し始めたと思われる例。

写真11. 副腎摘出後30日目家鬼甲状腺組織像。鉄へマ染色. $(\times 660)$ 機能回復が僅があつたと思われる 例，ミトコンドリアが幾分認められた。 